\title{
Effect of Brand Orientation on Entrepreneurship Creativity in Small Medium Enterprises Brand
}

\author{
Dadan Abdul Aziz Mubarok \\ Sekolah Tinggi Ilmu Ekonomi Indonesia Membangun (STIE-INABA) \\ Bandung, Indonesia \\ dadan.aziz@inaba.ac.id
}

\begin{abstract}
Brand orientation and entrepreneurship creativity are factors that must be considered by SMEs in implementing the brand. Integration both of these factors can increase the ability SMEs to manage the resources to create and pursue opportunities that are not recognized by competitors. Brand orientation and entrepreneurship creativity expected to be used as a model in the implementation of the brand in SMEs to create and build a strong brand and highly competitive. The purpose of this study is to propose a model that examines the impact of brand orientation on entrepreneurship creativity of SMEs for brand implementation in center of the shoe industry at Bandung. Design research using quantitative research explanatory. The study population is SMEs at Cibaduyut Bandung with a sample of 100 SMEs which already has its own brand. The sampling method with purposive sampling and analysis of data using multiple linear regression. The results showed that the brand orientation has an influence on the entrepreneurship creativity in implementation of brand shoes in SMEs Cibaduyut Bandung.
\end{abstract}

Key words: brand orientation, entrepreneurship creativity, SME's

\section{INTRODUCTION}

The use of current brand is not only done by the company large enterprises, but applied to small and medium enterprises or SMEs. Competitive conditions faced by SMEs today, demanding the SME business people to always study the market conditions and implement strategies and execute effective marketing activities. Based on this, it is one of the efforts to maintain and enhance the ability of SMEs to compete in today's competitive climate, is to implement a brand [1]. Consumers will give a higher appreciation for SMEs which have identity product or brand than the product of SMEs that do not have a brand [2]. Brand an important part in the decision making process of consumers who became one of the key in winning the consumer's choice [3]. Consumers believe that products branded is a representation of quality product. In addition, branded products have the advantage of increasing the efficiency and effectiveness of marketing that is able then to create long-term profit[4][5]. Today, the brand on SMEs not only as identity, but will be part of building a competitive advantage which contributes to increase sales and differentiate it from competitors' products[6][7].

Bandung as one of the cities in West Java Province, known as the City of Creative Industries that have the potential of small and medium enterprises or SMEs in industry and trade as a source of income, the economy and welfare. Based on data from the Department of Cooperatives SMEs Industry and Trade of Bandung in 2014, there were 30 business centers of SMEs in Bandung, which has the potential to become a business center as well as tourist attractions industry international class in the future and one of them is the center of Creative Industries Shoe Cibaduyut which have the advantage in manufacture of shoes with handmade techniques.

In 2007 , the number of businesses in the center of the shoe Cibaduyut reached 845 units that absorb approximately 3,556 workers. Investments that are embedded in this center, estimated to reach $\mathrm{Rp} 23.72$ billion with a production capacity of more than 4 million pairs every year.

However, during the period 2006 - 2015 based on data SMEs Development Installation of Cibaduyut, operating revenues in SMEs Cibaduyut decline reaching an average of $10 \%$ per year. This condition is caused due to increasing competition, the entry of imported products and the low awareness of the SMEs owner in implementing the brand that many consumers are turning to buy branded product imported.

The low implementation of the brand in SMEs is influenced by marketing objectives, brand management awareness, entrepreneurship orientation, budget available and market situation [4]. These characteristics, influence the owners of SMEs in implementing and managing brand [8]. Accordingly, the ability and intuitive of SMEs owners as a brand orientation is a factor must be consider because it will determine the extent to which SMEs can create a product with a unique brand to get the consumer attention [4],[9].

The success of SMEs owners doing business because they have managerial experience and unique knowledge [10]. In the process of running a business they must have entrepreneurship creativity to create something unique, able to face the risks and always make creativity and innovation to improve competitiveness [11]. Therefore, creativity as the core of entrepreneurship action affect the ability of SMEs owners to manage the business well as it will determine how far they are able to utilize the resources to acquire new profitable opportunities [12].

The focus of research on the brand in SMEs today, more emphasis is based on market orientation. However, characteristics, processes and internal dynamics of SMEs will determine the owners of SMEs in implementing and managing the brand as unique and as the identity of the product to achieve marketing success. 
Brand orientation is a brand strategy as a guide for SMEs on managing and implementing the brand. While entrepreneurship creativity is the ability of SME owners to manage their business utilizing the resources owned by the brand orientation to create a branded product. This condition leads to brand management awareness in SMEs has been a priority in business, and brand is a part of the business long term planning activities to encourage business owners able to produce something unique to gain the profit and consumers attention.

Based on the description above, the study aims to determine how brand orientation as the company's approach to enhance the ability to compete effect on entrepreneurship creativity as the activities of SMEs owners in utilizing the unique resources to create or obtain new opportunities in SMEs Cibaduyut Bandung

\section{LITERATURE REVIEW}

Brand is a company asset that can enhance the interest and attention of consumers to the product and be part of the company's patent of the products it produces [13]. Based on this, the brand can be used by companies to improve competitiveness by making the brand as the vision, mission, direction and goals, as well as corporate culture.

Brand in SMEs, can be used as the identity and description of the company's reputation as a key to long-term basis are able to overcome all the changes in the environment and can increase enterprise value[14]. Application of the brand in the SMEs should be a guideline owners to create the company's activities more competitive and able to manage its resources into something unique in a process of business activity [8][15]

Brand orientation is the company's approach to building a competitive advantage by using the brand that describes the characteristics, behavior and the ability of an organization to make the company more unique compared to competitors [6][16].

Brand orientation to guide the owner or manager in running a company, because it puts the brand as direction and policy in carrying out marketing activities, an important asset in the company, part of a long-term planning of the company [6][5].

The culture of SMEs is entrepreneurship, which is the character that must be possessed by any SMEs owners in running business with the ability to develop creativity and innovation by creating new business activity and ensuring survival [17][18][19]. Ability and knowledge of developing business opportunities obtained from the process and their activities of SMEs owner in managing a business that is familiar in the face of uncertainty, risk-taking, and desire to achieve success in business [17][18]. These conditions encourage them to constantly innovate and enhance creativity as two important dimensions that must be owned by SMEs in winning the competition [17]

Entrepreneurship orientation is the ability of an individual or organization used to seek change by means of its resources to get the opportunities that are not recognized by the competitors by way of proactive and innovative so as to create something new and unique [17][18][20]. Entrepreneurship orientation can be considered as entrepreneurship creativity because it is a process of creativity of individuals or organizations in creating or get something new [11].

Therefore, SMEs in doing business should have the following capabilities a). Search for changes is the ability of business owners to seek a change in the management of its business that aims to survive, so it can grow and competitiveness; b). Exploiting Opportunity is the ability of business owners to find every opportunity that an unknown competitor and; c). Create value the ability of business owners to create products or services that fit the needs and desires of consumers[17]-[19][21]

Brand orientation and entrepreneurial creativity are two different constructs but independent from each other. Brand orientation as the direction and long-term business policies relating to entrepreneurship creativity as the character and behavior of individuals or organizations in the management of SMEs [22]. Based on this, the application of the brand in the SME influenced by brand orientation that is expected to improve the entrepreneurship creativity of SME managers to create new and unique products and find opportunities that are not recognized by competitors [20].

\section{RESEARCH METHODOLOGY}

This study design using explanatory research to determine how the effect of brand orientation as a marketing policy, as the company's assets, and as a long-term planning which is an independent variable $(\mathrm{X})$ on the entrepreneurship creativity as a dependent variable ( $\mathrm{Y}$ ) which is an activity consisting of search for changes, exploiting the opportunity and create value to increase the brand implementation awareness in SMEs.

The study population is SMEs at Cibaduyut Bandung which already has its own brand. The research sample is composed of 100 SMEs owners obtained from purposive sampling technique.

The primary data collection technique for this study with a self-administered questionnaire. The questionnaire was design to measure determinant factors of brand orientation and entrepreneurship creativity. A five point Likert scale was used with point 1 being not important at all and point 5 very important as the anchors. SPSS is uses for data analysis with multiple linear regression. The selected method data analysis include descriptive analysis.

\section{FINDINGS AND DISCUSSIONS}

Based on the output SPSS version 20, the proposed model feasible to estimate the effect of brand orientation towards entrepreneurship creativity in SMEs at Cibaduyut Bandung (Table I). According the proposed model, brand orientation has an influence on entrepreneurship creativity in implementing brand shoes at SMEs Cibaduyut Bandung. 
TABLE I. PROPOSED MODEL

\begin{tabular}{|l|l|l|l|l|l|l|}
\hline \multicolumn{2}{|c|}{ Model } & $\begin{array}{c}\text { Sum of } \\
\text { Squares }\end{array}$ & Df & $\begin{array}{c}\text { Mean } \\
\text { Square }\end{array}$ & F & Sig. \\
\hline 1 & Regression & 22.170 & 3 & 7.390 & 587.039 & $.000 \mathrm{~b}$ \\
& Residual & 1.209 & 96 & .013 & & \\
& Total & 23.379 & 99 & & & \\
\hline
\end{tabular}

a. Dependent Variable: Y = Entrepreneurship Creativity

b. Predictors: (Constant), X3 = Brand as long term planning,

$\mathrm{X} 1=$ Brand as marketing policy, $\mathrm{X} 2=$ Brand as asset

Source : SPSS v 20 output

By Table I. The F-value indicates $0.000<0.05$, where the effect of brand orientation on entrepreneurship creativity simultaneously showed significant. This condition revealed based on research [22] where brand orientation relating to entrepreneurship creativity as the character and behavior of individuals or organizations in the management of SMEs

The proportion of the influence of brand orientation towards entrepreneurship creativity in the regression model based on the adjusted R-square of $94.7 \%$ while the remaining $5.3 \%$ is influenced by other factors which do not exist in Sherce regression model (Table II).

TABLE II. DETERMINANT FACTORS PROPORTION

\begin{tabular}{|c|c|c|c|c|c|}
\hline Model & $\mathbf{R}$ & $\begin{array}{c}\text { R } \\
\text { Square }\end{array}$ & $\begin{array}{c}\text { Adjusted } \\
\text { R Square }\end{array}$ & $\begin{array}{c}\text { Std. Error of } \\
\text { the Estimate }\end{array}$ & $\begin{array}{c}\text { Durbin- } \\
\text { Watson }\end{array}$ \\
\hline 1 & $.974^{\mathrm{a}}$ & .948 & .947 & .11220 & 2.257 \\
\hline
\end{tabular}

Source : SPSS v 20 output

Result showed by Table II, consistent with research by [4] which is determine factors for brand implementation conduct by characteristic, process and dynamic situation in SMEs. This condition illustrate there are many factors must be considered by SMEs owners in implementation of brand[4].

Based on research, the effect of brand orientation that consists of brand as marketing policy, brand as asset and brand as long term planning partially showed significant results on entrepreneurship creativity with the t-value $0.000<0.05$ with the following regression equation: $Y=0,811 \times 1+0,400 \times 2-0,205 \times 3$ (Table III).

Interesting things derived from the research, it is known that the brand as long term planning have a negative effect, this means SMEs at Cibaduyut Bandung although it has been applying the brand on products but do not put the brand as part of a long-term planning business activities. There by led revenue decreased by an average of $10 \%$ per year during the period 2006-2015 and have difficulty developing its business in creating new opportunities

This is different from the results [1] which revealed that the brand implementation for SMEs product in the future is able to increase the market demand, improve product quality and help promote the product becomes better known.

Different conditions if the brand used as part of long term planning, small business owners will be motivated to become more creative and innovative that gives them the opportunity in running its business[11][17][18][22].
TABLE III. EFFECT OF BRAND ORIENTATION ON ENTREPRENEURSHIP CREATIVITY

\begin{tabular}{|c|c|c|c|c|c|c|}
\hline \multirow{2}{*}{\multicolumn{2}{|c|}{ Model }} & \multicolumn{2}{|c|}{$\begin{array}{l}\text { Unstandardize } \\
\text { d Coefficients }\end{array}$} & \multirow{2}{*}{$\begin{array}{c}\begin{array}{c}\text { Standar } \\
\text { dized } \\
\text { Coefficie } \\
\text { nts }\end{array} \\
\text { Beta }\end{array}$} & \multirow[t]{2}{*}{$\mathbf{t}$} & \multirow[t]{2}{*}{ Sig. } \\
\hline & & B & $\begin{array}{c}\text { Std. } \\
\text { Error }\end{array}$ & & & \\
\hline 1 & $\begin{array}{l}\text { (Constan } \\
\text { t) } \\
\text { X1 = } \\
\text { Brand as } \\
\text { marketin } \\
\text { g policy } \\
\text { X2 = } \\
\text { Brand as } \\
\text { asset } \\
\text { X3 = } \\
\text { Brand as } \\
\text { long } \\
\text { term } \\
\text { planning }\end{array}$ & $\begin{array}{l}.058 \\
.793 \\
.404 \\
-.205\end{array}$ & $\begin{array}{l}.102 \\
.029 \\
.032 \\
.032\end{array}$ & $\begin{array}{l}.811 \\
.406 \\
-.205\end{array}$ & $\begin{array}{l}.566 \\
27.691 \\
12.601 \\
-6.476\end{array}$ & $\begin{array}{l}.573 \\
.000 \\
.000 \\
.000\end{array}$ \\
\hline
\end{tabular}

a. Dependent Variable: $\mathrm{Y}=$ Entrepreneurship Creativity

Source : SPSS v 20 Output

Based on the survey results revealed that brand orientation to be a part of brand implementation in SMEs [6]. Brand orientation to be an alternative for SMEs strategy company as part of the synergy in implementing the brand [23].

Brand orientation based on the results of the study, implemented by SME owners as marketing policy and asset. Both factors became the basis for SME owners in Cibaduyut Bandung to create a competitive product and be guide in conducting marketing activities. This condition is consistent with research [3][6][7][13] where the brand should be able to increase the competitive ability of a product to become more profitable.

Based on research entrepreneurship creativity is a factor that must be considered as it relates to the ability of business owners to manage resources and business growth [24]. Entrepreneurship orientation can be referred to as the entrepreneurial creativity as it relates to the creative process business owners to create something unique accordance with the needs and desires of the market [11]. The entrepreneurship creativity led the SMEs for brand implementation for creating a new product more profitable.

\section{CONCLUSION AND SUGGESTIONS}

Brand orientation and entrepreneurship creativity as part of the implementation strategy of the brand in SMEs, are expected to encourage the development of the brand is not as identity alone but be one way to improve competitiveness, able to build a strong brand and creating innovation and creative marketing to increase brand aware and brand image SMEs. Brand orientation as synergies SMEs to implement brand strategies play a role in improving the entrepreneurship creativity of business owners to acquire or create opportunities that are not recognized by competitors by managing something unique and new.

To increase brand management awareness apply, it is necessary to the role of government in disseminating the 
importance of brand for SMEs, providing incentives to SMEs who have chosen the brand and provide legal protection of patents or intellectual property rights to prevent the emergence of counterfeit products. Future studies are expected to be analyzed in addition to these two factors so as to provide a complete understanding of the role of the brand in SMEs and what challenges affecting the implementation of the brand in SMEs.

\section{REFERENCES}

[1] A. Chakraborty, S. K. Deb, and A. Choudhary, "Importance of Brand for SMEs," J. Bus. Manag. Soc. Sci. Res., vol. 2, no. 3, pp. 45-48, 2013.

[2] H. Surachman and G. Benny, "Apresiasi Konsumen terhadap Merek Dalam Negeri," Bul. Ilm. Litbang Perdagang., vol. II, no. 2, pp. 159 186, 2008.

[3] P. Kotler and K. L. Keller, Marketing Management, 14th ed. Pearson, 2012.

[4] K. Frank B, G, J, M, "Successful brand management in SMEs : a new theory and practical hints," J. Prod. Brand Manag., vol. 14, no. 4, pp. $228-238,2005$.

[5] H. Y. Wong and B. Merrilees, "Closing the marketing strategy to performance gap: the role of brand orientation," journal Strateg. Manag., vol. 15, no. 5, pp. 384-402, 2007.

[6] H. Y. Wong and B. Merrilees, "A brand orientation typology for SMEs : a case research approach," J. Prod. Brand Manag., vol. 14, no. 3, pp. 155-162, 2005.

[7] R. Abratt and N. Kleyn, "Corporate identity , corporate branding and corporate reputations Reconciliation and integration," Eur. J. Mark., vol. 46, no. 7/8, pp. 1048-1063, 2012.

[8] G. Horan, M. O. Dwyer, S. Tiernan, G. Horan, and S. College, "Exploring management perspectives of branding in service SMEs," $J$. Serv. Mark., vol. 25, no. 2, pp. 114-121, 2011.

[9] R. Mitchell, K. Hutchinson, and B. Quinn, "A framework for SME retail branding," J. Mark. Manag., no. July 2015, pp. 1-33, 2015.

[10] M. W. Staniewski, "The contribution of business experience and knowledge to successful entrepreneurship is," J. Bus. Res., 2016.

[11] W. E. Mcmullan and T. P. Kenworthy, Creativity and Entrepreneurial Performance A General Scienti c Theory. London: Springer, 2015.
[12] D. A. Shepherd and H. Patzelt, The ' heart' of entrepreneurship: The impact of entrepreneurial action on health and health on entrepreneurial action," J. Bus. Ventur. Insights, vol. 4, pp. 22-29, 2015.

[13] J. N. Kapferer, The New Strategic Brand Management, 4th Editio., vol. 4. 2008 .

[14] T. Abimbola, A. Kocak, C. Vallaster, M. Spence, and L. H. Essoussi, "Qualitative Market Research: An International Journal Article information :," Qual. Mark. Res. An Int. J., vol. 10, no. 4, pp. 416-438, 2007.

[15] T. Abimbola, "Branding as a Competitive Strategy for Demand Management in SMEs," J. Res. Mark. Entrep., vol. 3, no. 2, pp. 97-106, 2001.

[16] J. Gromark and F. Melin, "The underlying dimensions of brand orientation and its impact on fi nancial performance," J. Brand Manag., vol. 18, no. 6, pp. 393-409, 2011.

[17] E. Kabukcu, "Creativity process in innovation oriented entrepreneurship : The case of Vakko," Procedia - Soc. Behav. Sci., vol. 195, pp. 1321-1329, 2015.

[18] L. Duman, A. Bedük, A. S. Köylüoğlu, and K. Ay, "Entrepreneurship Culture at SMEs : A Case Study in Konya," Procedia - Soc. Behav. Sci., vol. 207, pp. 492-501, 2015.

[19] D. Hjorth and R. Holt, "Journal of Business Venturing Insights It" s entrepreneurship , not enterprise : Ai Weiwei as entrepreneur," J. Bus. Ventur. Insights, vol. 5, pp. 50-54, 2016.

[20] D. Ucbasaran, P. Westhead, and M. Wright, "The extent and nature of opportunity identification by experienced entrepreneurs," J. Bus. Ventur., vol. 24, no. 2, pp. 99-115, 2009.

[21] T. B. Ward, "Cognition, creativity, and entrepreneurship," J. Bus. Ventur., vol. 19, pp. 173-188, 2004.

[22] V. Tavares, "Brand Management in SMEs: Conceptualization of Differences and Research Agenda," Eur. J. Appl. Bus. Manag., vol. 1, no. 1 , pp. $128-153,2015$.

[23] M. Urde, C. Baumgarth, and B. Merriless, "Brand orientation and market orientation - From alternatives to synergy," J. Bus. Res., no. January, 2011.

[24] F. Eggers, S. Kraus, M. Hughes, S. Laraway, and S. Snycerski, "Implications of customer and entrepreneurial orientations for SME growth," Manag. Deciision, vol. 51, no. 3, pp. 524-546, 2013. 